\title{
EVIDENCE-BASED INTERVENTIONS FOR ASD: A FOCUS ON APPLIED BEHAVIOR ANALYSIS (ABA) INTERVENTIONS
}

\author{
E.L. GRIGORENKO ${ }^{\mathrm{a}, \mathrm{b}}$, S. TORRES ${ }^{\mathrm{b}}$, E.I. LEBEDEVA ${ }^{\mathrm{c}, \mathrm{d}}$, Y.A. BONDAR ${ }^{\mathrm{d}, \mathrm{e}}$ \\ ${ }^{a}$ St. Petersburg State University, $7 / 9$ University Embankment, St. Petersburg, 199034, Russian Federation \\ ${ }^{b}$ University of Houston, 4800 Calhoun Rd, Houston, TX 77004, USA \\ ${ }^{\circ}$ Institute of Psychology, Russian Academy of Sciences, 13/1 Yaroslavskaya Str., Moscow, 129366, \\ Russian Federation \\ ${ }^{d}$ Association of Non-profit Organizations Created by Parents with Autism Spectrum Disorders "Autism \\ Regions", 90 Dubininskaya Str., Moscow, 115093, Russian Federation \\ ${ }^{e}$ Novosibirsk State University, 2 Pirogova Str., Novosibirsk, 630090, Russian Federation
}

\begin{abstract}
Given the explosion in published psychological and educational interventions for autism spectrum disorder (ASD) over the past several years, this review highlights the latest trends for children with complex learning and developmental needs. Recent efforts in intervention research focus on meeting standards of scientific evidence and emphasize the importance of strict adherence to the principles of high quality research and evidence-based practice. According to recent systematic reviews, all evidence-based comprehensive intervention programs for children with ASD are based to some extent on the scientific discipline of Applied Behavior Analysis (ABA). Such intensive behavioral interventions have the power to improve the trajectory of development of a child with ASD. In particular, meta-analytical studies have demonstrated substantial improvement in IQ scores and adaptive behavior in children receiving early intensive ABAbased comprehensive interventions. Moreover, the majority of evidence-based focused interventions for ASD are either ABA-based or are included in ABA-based comprehensive intervention programs. There is a growing interest in modular interventions, which allow a high-degree of individualization for each child with ASD, while meeting the standards of evidence-based practice. An uptick in the number of rigorous evaluations of different interventions conducted in real-world settings with outcomes focused on core deficits in ASD augurs well for wide dissemination and implementation by qualified nonspecialists in the community.
\end{abstract}

Keywords: autism spectrum disorder, behavioral interventions, applied behavior analysis, evidence-based interventions.

Autism spectrum disorder (ASD) is a lifespan developmental disorder that manifests within the first three years of life primarily through difficulties in social communication and social interaction, and the presence of focused repetitive, restrictive or stereotyped behaviors, interests, and activities (APA, 2013). This disorder is characterized by striking heterogeneity both in its presentation (i.e., the

Preparation of this article was supported by the RFBR (award № 17-29-02384, PI: Grigorenko) and the Way Out Foundation. 
variability in levels of language, intellectual functioning, and presence of problematic behaviors) and etiology (i.e., the similarity in autistic features among many disorders of different causes).

The prevalence rate of ASD has surged since over 70 years ago, when the disorders were first described by Kanner (1943) and Asperger (Frith, 1991). Although the reasons for this increase remain unclear, it is partially attributable to the improvement in and availability of diagnosis (Hertz-Picciotto \& Delwiche, 2009). In the United States (based on data from 11 different states) in 2014, one in 59 8-year olds were identified with an ASD, four times more boys than girls (https://www.cdc.gov/features/new-autism-data/index.html).

A cure for ASD has not been identified. ASD treatment requires an orchestrated effort from multiple care providers and needs to be highly individualized and multifaceted (Warren et al., 2011), including early and intensive behavioral strategies, tailored educational interventions, continued support through major life competencies and milestones, and therapies for better clinical outcomes. The cost for quality ASD treatment can be quite high; over the lifespan of an individual with ASD, expenses can go up to US $\$ 2.4$ million (\$2.4 million for a child with and $\$ 1.4$ million for a child without intellectual disability) per family (Buesche, Cidav, Knapp, \& Mandell, 2014). Moreover, as these estimates do not account for collateral effects of ASD, such as stress on caregivers and families, they may underrate the broader societal impact of these disorders.

\section{Evidence-based practices and ASD interventions}

Due in part to the devastating presentation of severe ASD and to effective parent and clinician advocacy, a wide range of interventions have been developed aimed at remediating and supporting individuals with ASD. For example, the USA alone has allocated more than $\$ 1.4$ billion for research on ASD, and a substantial chunk of this research has focused on interventions (IACC, 2017). The interventions in the field of ASD range widely from scientifically validated procedures to parent-developed self-help management approaches, to apparently charlatan and fad treatments (Freeman, 2007; Reichow, Doehring, Cicchetti, \& Volkmar, 2011). The confluence of rising pressure from consumers (i.e., individuals with ASD and their families), and the broad system-wide provider response (influenced by increasingly precise calculations of the financial and social costs associated with ASD), pushed the need for the development and appraisal of ASD interventions to the forefront of the field. The investment required accountability, thus the issue of identifying evidence-based interventions (EBI) for the treatment of ASD became central.

In high-income countries, where practitioners are highly regulated by licensure and professional organizations, a common standard is to base the selection of intervention practices on scientific evidence of efficacy (Suhrheinrich, Hall, Reed, Stahmer, \& Schreibman, 2014). This standard has arisen from the evidence-based medicine movement that emerged from England in the 1960s (Sackett, Rosenberg, Gray, Haynes, \& Richardson, 1996). One of many outcomes of this movement has 
been the establishment of the Cochrane Collaboration to host reviews of the literature about scientifically supported practices and interventions. This movement has impacted not only medicine, but other fields in which human beings undergo various types of treatments. Driven by this movement, in the 1990s, Division 12 (Society of Clinical Psychology) of the American Psychological Association established criteria for classifying intervention practices as "efficacious" or "probably efficacious," which provided a precedent for quantifying the amount and type of evidence needed to establish a psychosocial intervention practice as evidencebased (Chambless et al., 1996). Subsequently, other professional organizations such as the Council for Exceptional Children (Odom et al., 2004), the US National Association for School Psychology (Kratochwill \& Shernoff, 2004), and the American Speech and Hearing Association, have developed corresponding standards, establishing the criteria for the level of evidence needed for a practice to be called EBI. This is not the only typology: other researchers have distinguished between evidence-based programs and evidence-supported programs (Cook \& Cook, 2013); in many instances, including here, these terms are used interchangeably.

The EBI approach has changed the professional standards in all of the diagnosis-specific subfields of clinical psychology and aligned disciplines (e.g., education and social work), including the field of ASD. Prior to the 21st century, the identification of EBI for individuals with ASD was accomplished primarily by means of narrative reviews conducted by groups of researchers and practitioners or organizations (Wong et al., 2015). Although useful at that time, as they were the only means for carrying out evenhanded comparisons of various treatment approaches, such reviews did not rely on a standard process for searching the literature, a stringent review process that incorporated clear criteria for including or excluding studies, a systematic process for organizing the information into sets of practices, an established procedure for identifying treatment outcomes, and a statistical routine for evaluating the treatment-related effect sizes. Subjective evidence such as testimonials, anecdotes, and personal accounts were deemed not reliable.

The general field of research into EBI has developed substantially over the last three decades. There are now guidelines and standard instruments for evaluating treatment studies, and systematic and meta-analytic reviews are common. These changes have impacted and reshaped the field of ASD as well. Many traditional systematic review processes such as the Cochrane Collaborative relied primarily on dominant methodologies for evaluating interventions, namely a randomized experimental group design (also called randomized control trial or RCT). Whereas early systematic reviews of ASD interventions (Rogers, 1998) did not identify any RCT on psychological or behavioral interventions for ASD, a review conducted ten years later (Rogers \& Vismara, 2008) located five RCTs, and the next five years produced approximately 50 additional RCTs (Weitlauf et al., 2014). The pace of ASD-related intervention research reflects a coordinated investment of federal and private funding organizations that continues to accelerate rapidly (IACC, 2017).

Importantly, additional methodologies have been acknowledged as instrumental in systematic and meta-reviews. Thus, the Cochrane Collaborative previously 
excluded single case design (SCD) studies (Kratochwill \& Levin, 2014), omitting a vital experimental research methodology prevalent in the field of ASD. Now SCD is recognized as a valid scientific approach, representing and illuminating the major body of research literature on interventions for children and youth with ASD. There are explicit expectations that the intervention literature will follow the standards for transparent reporting of study procedures, such as the Consolidated Standards of Reporting Trials (CONSORT) Statement for RCT (Moher et al., 2010) and the Transparent Reporting of Evaluations with Nonrandomized Trials (TREND) Statement for quasi-experimental studies (Fuller, Pearson, Peters, \& Anderson, 2012).

Unfortunately, despite the massive research and practice effort that has unfolded over the last four decades, the field is still looking for a cure for ASD. Yet, there are multiple ASD interventions whose number and availability can be estimated by the sheer quantity of empirical publications (hundreds per year) and by the growing number of systematic- and meta-reviews of these publications; yet far from all of these interventions are deemed effective. When ASD interventions are described, two different types of treatment are distinguished, comprehensive and focused.

Comprehensive treatment models (CTM, comprehensive interventions) consist of a set of elements (interventions) developed within a particular conceptual framework and conceived to result in a broad learning or developmental impact on the core deficits of ASD (Wong et al., 2015). To illustrate, in 2010 there were 30 CTM programs operating within the USA (Odom, Boyd, Hall, \& Hume, 2010) that could be characterized roughly according to their organization (i.e., around a conceptual framework), operationalization (i.e., procedures manualized), intensity (i.e., substantial number of hours per week), longevity (i.e., occur across one or more years), and breadth of outcome focus (i.e., multiple outcomes targeted, such as communication, behavior, social competence). Examples of CTMs are the Lovaas model (Lovaas, 1987), the Early Start Denver Model (ESMD; Dawson et al., 2010), Learning Experiences and Alternate Program for Preschoolers and their Parents (LEAP; Strain \& Bovey, 2011), More than Words (Carter et al., 2011), Pivotal Response Treatment (PRT; Koegel \& Koegel, 2012), Treatment and Education of Autistic and Related Communication Handicapped Children (TEAACH; Mesibov, Shea, \& Schopler, 2004), Joint Attention, Symbolic Play, Engagement and Regulation (JASPER; Kasari et al., 2014) among others.

Focused interventions (FI) are designed to address a single (or a limited number of) skill(s) or goal(s) of a student with ASD (Odom, Collet-Klingenberg, Rogers, \& Hatton, 2010). FI tend to be defined operationally, target specific learner outcomes, and unfold over shorter time periods than CTMs, for as long as a specific outcome is achieved. FI are the construction blocks or modules of CTMs and educational programs for individuals with ASD. For example, an FI peer-mediated instruction intervention is a key component of the LEAP model. Examples of FI are the Picture Exchange Communication System, PECS (Bondy \& Frost, 2001); functional behavior assessment, $F B A$ (Didden et al., 1997); and the PEAK, Promoting the Emergence of Advanced Knowledge (Dixon et al., 2017). 
To navigate these interventions and appraise their efficacy, summative reviews are conducted that meet the requirements of the field of EBI. One early widelycited review of ASD interventions (Rogers, 1998) concluded that no ASD interventions at that point could be classified as EBI. A decade later, another influential review (Rogers \& Vismara, 2008) deemed ASD interventions as promising but preliminary; that review classified only one intervention as well established, none as probably efficacious, and three as possibly efficacious. One of the most recent reviews (Smith \& Iadarola, 2015) identified two interventions as well-established, three as probably efficacious, and five as possibly efficacious. The only intervention labeled as "well established" in 2008 was a comprehensive individual intervention based on scientifically established principles of applied behavior analysis, ABA (Smith, 2011). The two interventional approaches labeled as "well established" in 2015 were individual, comprehensive ABA-based and teacher-implemented, focused interventions based on a blend of ABA with developmental social-pragmatic (DSP) models, also called developmental, interactive, transactional, or interpersonal (Ingersoll, Dvortcsak, Whalen, \& Sikora, 2005).

All high-quality reviews of ASD interventions today consistently and unequivocally identify ABA-based interventions as EBI and the first-choice treatment for individuals with ASD (Maglione, Gans, Das, Timbie, \& Kasari, 2012; National Autism Center, 2015; National Professional Development Center, 2013; New York State Department of Health Bureau of Early Intervention, 2017; Weitlauf et al., 2014; Wong et al., 2013). These reviews are cumulative interpretations of the ASD intervention literature which, since the 1980s, has consistently shown that interventions utilizing ABA have been effective in decreasing problem behavior and promoting the acquisition of new skills in children with ASD. Thus, in 2014, the Agency for Healthcare Research and Quality published a systematic review of existing and new RCT and cohort studies, in which it was established that an ABAbased early intensive behavioral intervention (EIBI) delivered over an extended time frame leads to clinically and statistically significant gains in cognitive ability, language, and adaptive skills (Weitlauf et al., 2014). Notably, although not always rigorously conducted, comparative studies of various interventions also provide evidence that ABA-based interventions constitute the most effective approach available to treat ASD. As of today, studies have demonstrated the effectiveness of several EIBI programs based on the principles of ABA, specifically, the Lovaas model and ESDM. Moreover, comprehensive reviews have identified interventions that are not EBI and cannot be recommended, specifically, auditory integration therapy, developmentally-based individual difference relationship-based intervention (DIR)/Floortime, Social Communication, Emotional Regulation, and Transactional Support (SCERTS), sensory integration therapy, touch therapy, music therapy, hormones (corticotrophin [ACTH] and Secretin), vitamin therapies, and special diets (New York State Department of Health Bureau of Early Intervention, 2017). Some treatments - i.e., facilitated communication, bonding (attachment) therapies, holding therapy, and psychoanalysis - have been deemed to be quite harmful and are recommended to be avoided (Foxx, 2008; Smith, 1996). 
Of note is that empirically supported treatments for ASD have commonalities that, in the view of many investigators, can be regarded as a set of best practices that should always be incorporated into services offered to children with ASD (Iovannone, Dunlap, Huber, \& Kincaid, 2003). Specifically, for an ASD treatment to be efficacious, it should utilize: (1) individualized services and supports by making use of the particular interests and individual learning style of each child with ASD to increase engagement in activities through interventions such as reinforcement systems and the incorporation of preferred activities into intervention sessions; (2) systematic intervention planning by selecting goals and instructional procedures based on a data-based assessment of each child, monitoring progress, and troubleshooting as needed; (3) comprehensible, structured environments such as using visual schedules to help children with ASD anticipate transitions between activities and organized work spaces to facilitate task completion; (4) specific intervention content to address the impairments in social communication and the restricted, repetitive behaviors that define ASD; (5) a functional approach to problem behavior: assessing the function or purpose of the behavior and selecting intervention strategies based on this assessment; and (6) family involvement to promote consistency between home and the intervention setting, take advantage of the family's knowledge of the child with ASD, and overcome difficulties that children with ASD are likely to have in transferring information from one setting to another.

\section{ABA as a guiding principle of ASD interventions}

The fundamental premise of all forms of ABA as a theoretical model is that for learning to occur three components are necessary. First, a stimulus must be present to cue the child's response (antecedent). Second, the child should respond by demonstrating a behavior. Third, there should be a consequence that will increase (reinforce) or decrease (punish) the future frequency of that behavior (Skinner, 1938). Skinner, whose work formed the foundation of ABA, demonstrated that in a carefully constructed environmental context, behaviors that produce favorable outcomes will continue to occur through the process of reinforcement and those behaviors that do not produce favorable consequences will decrease over time, or be extinguished. His antecedent-behavior-consequence framework is used to teach a range of skills (e.g., imitation, communication and social skills) that are deemed essential for further learning and development. Operant procedures used to establish new responses include shaping, prompting, extinction, reinforcement, modeling, among others. It is important to state that the principles and procedures of ABA have been used to treat a wide variety of behavior aberrations such as academic delays and addiction (Fisher, Piazza, \& Roane, 2011).

It has been observed that the first publication demonstrating the efficacy of Skinner's theory (1938) with children with ASD appeared in the early 1960s (Wolf, Risley, \& Mees, 1964). Yet, active interest in ABA-based interventions was ignited only in the 80 s by a landmark study in which one-half of the patients assigned to treatment were able to be placed in a neurotypical classroom and complete first grade (Lovaas, 1987). This study, conducted within the UCLA-Young 
Autism Project, utilized an intensive version of ABA-based treatment for ASD (Lovaas model), which is commonly referred to as EIBI. As originally conceived, EIBI is a comprehensive treatment model delivered 5-7 days per week, several hours per day for up to 25-40 hours per week (Myers \& Johnson, 2007). In its typical presentation, the treatment is initiated in a one-to-one format with a focus on the elimination of atypical behavior and the establishment of learning skills. Later, the treatment may become more group oriented and less structured while focusing on more complex cognitive and social skills (Smith \& Iadarola, 2015). In Lovaas's version, the EIBI model relied heavily on the discrete trial training (DTT) technique, which focuses on teaching skills in a repeated and brief fashion with specific instruction (the "discriminative stimulus") while minimizing extraneous details, thereby making the instruction "discrete." Correct responses are reinforced through various reinforcers, including but not limited to praise, whereas incorrect responses do not produce such positive reaction or are corrected while repeating the instruction. Importantly, DTT assumes an ongoing data collection and data analysis. The data are collected on a trial-by-trial basis or on a subset of trials, and are used to determine the child's rate of progress and whether procedural modifications are warranted. As children progress in skill development, this model typically is applied for a shorter duration - e.g., 15 hours per week - to address more complex social or other behavior - e.g., perspective taking.

Since the early versions of ABA-based treatment of ASD, the field of ABAbased research and practice has greatly expanded; behaviorally based interventions are now utilized to address a wide range of core symptoms of ASD, as well as challenging behaviors and comorbid conditions. ABA describes fundamental principles of the process that encompasses a field of study and is not just a single treatment for ASD. Thus, today ABA-/behavior-based interventions encompass a large number of methods and procedures. Yet, they are often grouped together (although they vary markedly in their objectives, content, structure, and effectiveness) by inexperienced consumers (researchers, practitioners, and parents) who are not very familiar with the multiplicity of diverse applications of ABA to the treatment of ASD.

Traditional ABA-based interventions are aimed to elicit behavioral modifications through highly intensive and structured trials, where adult-chosen stimuli are repeatedly presented to induce target behaviors in individuals with ASD, with correct responses reinforced (Vismara \& Rogers, 2010). More recently, advancements in ABA have led to more individualized and comprehensive treatments to target a wide range of adaptive behaviors that follow a more natural and normal developmental sequence (Thompson, 2013; Virués-Ortega, 2010).

In general, children who show behavior problems and skill deficits in multiple areas are candidates for comprehensive (immersive) treatments that might be conducted at high intensity in an effort to address the core symptoms and behavioral correlates of ASD through the implementation of a comprehensive intervention. Children who have relatively mild forms of ASD might be candidates for more timelimited or focused interventions. Practitioners can either adopt a CTM (again, many of which use specific FI) or build an individualized program combining multiple FI; 
the latter appears to be more popular (Bernstein, Chorpita, Daleiden, Ebesutani, \& Rosenblatt, 2015; Kasari, 2015). Below we provide selected illustrations of comprehensive and focused ASD treatments and discuss evidence of their effectiveness for treating ASD.

\section{Effectiveness of ABA-based interventions}

The effectiveness of ABA-based interventions in their various incarnations has been the subject of numerous meta-analytic studies (Eldevik et al., 2009, 2010; Estes et al., 2015; Kuppens \& Onghena, 2012; Makrygianni, Gena, Katoudi, \& Galanis, 2018; Makrygianni \& Reed, 2010; Peters-Scheffer, Didden, Korzilius, \& Sturmey, 2011; Reichow, Barton, Boyd, \& Hume, 2012; Reichow \& Wolery, 2008; Spreckley \& Boyd, 2009; Virués-Ortega, 2010). These studies vary in the interventions evaluated (CTM, FI or others), the designs used (RCT, SCD or other), the samples ascertained (age and diagnosis severity), and outcomes studied (core or associated features of ASD). This diversity leads to the challenge of evaluating the degree of their efficacy and the parameters that may contribute most to their effectiveness (Makrygianni et al., 2018). Yet, the field arrives to the same conclusion over and over again: there is unequivocal evidence for ABA-based interventions as an effective, and at this time first-choice, treatment for children with ASD.

Where there are equivocal findings is the precision of the estimates with which the global treatment effectiveness of the ABA family of interventions is translated into increases or improvement (in IQ scores, language skills, and adaptive behavior), and how it is translated into decreases and extinction (in autism-related symptomatology and/or symptom intensity, in the need for support during school inclusion, and in challenging behavior). To illustrate, Lovaas (1987) reported that $47 \%$ of the children with ASD who received long-term ABA-based comprehensive interventions achieved levels of normal intellectual and educational functioning as compared to only $2 \%$ of those children with ASD in a control group. Early metaanalyses have found similar improvement rates for children in ABA-based interventions as compared to those in control groups (Eldevik et al., 2009; Peters-Scheffer et al., 2011). A more recent (Reichow et al., 2012) meta-analysis presented an average effect size of $\mathrm{g}=0.69$ for adaptive behavior, $\mathrm{g}=0.76$ for IQ, $\mathrm{g}=0.76$ for communication skills, $\mathrm{g}=0.42$ for socialization, and $\mathrm{g}=0.55$ for daily living skills. The most recent meta-analysis (Makrygianni et al., 2018) indicated that ABA-based comprehensive programs are very effective in improving intellectual abilities ( $g=0.740)$; moderately to very effective in improving communication skills $(g=0.650)$, expressive-language skills $(g=0.742)$ and receptive-language skills $(g=0.597)$; moderately effective in improving IQ, indicated by non-verbal tests $(g=0.463)$, adaptive behavior (in total) $(g=0.422)$, and socialization $(\mathrm{g}=0.444)$; and had low effectiveness in improving daily living skills $(\mathrm{g}=0.138)$. Based on these figures, the collective effectiveness of the family of ABA-based interventions is moderate to high.

These impressive results have made an important impact on healthcare in the USA. Many publicly funded early intervention and preschool programs now also 
offer ABA-based interventions (Simpson, Mundschenk, \& Heflin, 2011). Similar initiatives have taken place in Canada (Perry et al., 2008), the United Kingdom (Kendall et al., 2013), and elsewhere.

However, although both academic evidence and public opinion point to ABAbased EBI as the preferred line of treatment for ASD, there is substantial opposition to the utilization of ABA. The push for ABA-based interventions has met considerable resistance on a number of fronts, including educational and governmental agencies not wishing to pay for expensive individualized programs. There are also professionals opposing ABA-based EBI who are either unfamiliar with ASD, or have philosophical perspectives antithetical to ABA, or who carry agendas that involve the promotion of competing approaches (Metz, Mulick, \& Butter, 2005; Smith, 2005).

Families of children with ASD have the right to use, and have used, a variety of services to help their children (Thomas, Morrissey, \& McLaurin, 2007). There are reports in the literature that some parents are actively discouraged from obtaining ABA-based interventions (Grindle, Kovshoff, Hastings, \& Remington, 2009); this deterrence is driven typically by one or a combination of ignorance of the ABA literature, ill will, or financial interests. Importantly, when parents themselves are surveyed, they project positive attitudes regarding the usage of ABA-based interventions in the treatment of their children. Thus, when parents of children who graduated from ESDM were asked to evaluate the program, they rated their experiences with ESDM positively and rated it as socially-valid (Ogilvie \& McCrudden, 2017). Similarly, parents of children treated with a variety of homebased ABA-based programs highlighted the overwhelmingly positive impact the interventions had on their children and deemed these interventions as sociallyvalid. The concept of social validity indicates how acceptable a given treatment (i.e., treatment acceptability) is to the population for which it was designed. A sociallyvalid intervention generally has a positive effectiveness and long-term trajectory.

Thirty-some years after the work of the UCLA Young Autism Project, the children are now adults. There are now studies on optimal outcomes of ASD in adulthood, since ASD is a life-long developmental disorder; that is, approximately $5-18 \%$ of individuals with an early ASD diagnosis are projected to, by adolescence (Helt et al., 2008), have no symptoms of ASD, and indeed to be behaviorally indistinguishable from their peers with a history of typical development. It has been documented that optimal outcome individuals generally receive earlier and more intense interventions based on ABA (Orinstein et al., 2014). Given the evidence in the literature on ASD, depriving or unjustifiably limiting exposure to high-quality ABA-based programs substantially lowers the chances of children with ASD reaching optimal outcomes in adulthood.

An important feature of intervention research is that evidence-based practice is a dynamic, not static, concept. The intervention literature is highly active and formulates new questions and challenges for researchers in an ongoing fashion. One such challenge in the field of developmental disorders in general and ASD in particular is the challenge of "non-responders," that is, children, who do not respond to EBI, regardless of how effective it has been shown to be in research studies. The 
dearth of information about the mediators and moderators that differentiate children's responses to EBI is widely acknowledged in the field, and there is a need for studies that establish guidelines for the prediction and monitoring of how an individual child with ASD will respond and is responding to a particular treatment. Such guidelines are especially important for CTM, given the extensive commitment of time and resources that these interventions entail (Smith \& Iadarola, 2015). There are already developments with regard to monitoring specific benchmarks deemed to be informative in determining whether a given intervention is progressing as intended. Moreover, there are suggestions for remedial strategies to consider when the intervention is not progressing (Ferraioli, Hughes, \& Smith, 2005). The greater the palette of EBI, the higher the chance of a "match" between a particular child with ASD and a particular EBI that is beneficial for that particular child.

There is a growing body of longitudinal analyses that are illuminating how child and family characteristics influence the course (i.e. initiation, continuation, and adherence) of ABA-based interventions (Kasari, 2015). Among the most commonly named child characteristics that matter, cognitive functioning, age at intervention entry, and social engagement are mentioned. Yet, the available information on child characteristics differentiating treatment outcome is limited.

It is also important to note that families differentially engage with treatment (Croen, Shankute, Davignon, Massolo, \& Yoshida, 2017). For example, among 293 insured children referred for ABA-based EBI, 23\% never initiated treatment. Among those initiating treatment, $31 \%$ discontinued treatment within 1 year of treatment initiation, and only $15 \%$ received $80 \%$ or more of the recommended treatment hours. Among positive predictors associated with treatment engagement were younger age at referral to treatment, private health insurance, and receiving more than 10 hours per week of EBI. Among negative predictors associated with treatment discontinuation were co-occurring psychiatric and medical conditions. Therefore, in helping the family select and implement EBI, it is essential to consider both child and family characteristics and assist families in adhering to the conditions of the intervention that are essential for its success.

\section{Conclusion}

In summary, ABA-based EIBI are the only evidence-based approach to providing comprehensive, individualized interventions for children with ASD. Such interventions have the power to alter the ASD trajectory of development. Importantly, the majority of evidence-based, focused interventions are either ABAbased or are included in ABA-based EIBI. There are factors that determine the resulting effectiveness of EIBI. Among such factors are the mode of EIBI delivery (where and by whom), the length of EIBI, and group (e.g., gender and ethnicity) and individual (e.g., general cognitive functioning) characteristics of children receiving EIBI. Moreover, there are multiple unanswered questions, such as the effectiveness of ABA-based interventions for adults with ASD and the role of ABA principles in educational and vocational training of individuals with ASD. 
The majority of adults with ASD do not live independently (Bruder, Kerins, Mazzarella, Sims, \& Stein, 2012), although outcomes are much better for those adults who received early diagnoses and appropriate treatment as children (Orinstein et al., 2014). Thus, early diagnosis and EBI starting as early as possible, within the first year of life, are imperative, as the need for better outcomes in adulthood are not only an increasing concern from a humanistic (Orinstein et al., 2014), but also from an economic perspective. This long-term perspective should encourage the professionals developing interventions for individuals with ASD to follow and respect the standard of providing the field with EBI. Short-term, to establish a network of effective support for individuals with ASD in Russia, what is crucial is the policy that guarantees that the federal support system utilizes only the most effective EBI.

Children and youth with ASD and their families should expect advances in intervention science to lead to better outcomes. This outlook to better outcomes is anchored in the necessity of translating scientific results into intervention practices that service providers may access, and provide professional development and support for implementing the practices with fidelity. It is important to acknowledge that the quickly growing field of implementation science in developmental disorders in general and ASD in particular may provide the needed guidance for such a translational process. Moreover, professional development models for teachers and service providers working with children and youth with ASD have turned to incorporating an implementation science approach (Odom et al., 2015). Such a movement from science to practice is a clear challenge and also an important next step for the field. Similarly, educating the consumers of these interventions (i.e., parents, teachers, and therapists of individuals with ASD) about EBI practice is also a challenge that should shape consumer standards by rejecting interventions that are not substantiated by empirical evidence. Obtaining such evidence is hard work, but without it, interventions might harm, not heal.

\section{References}

APA. (2013). Diagnostic and statistical manual of mental disorders (5th ed.). Washington, DC: American Psychiatric Association.

Bernstein, A., Chorpita, B. F., Daleiden, E. L., Ebesutani, C. K., \& Rosenblatt, A. (2015). Building an evidence-informed service array: Considering evidence-based programs as well as their practice elements. Journal of Consulting and Clinical Psychology, 83, 1085-1096. doi:10.1037/ccp0000029

Bruder, M. B., Kerins, G., Mazzarella, C., Sims, J., \& Stein, N. L. (2012). Brief report: The medical care of adults with autism spectrum disorders: Identifying the needs. Journal of Autism and Developmental Disorders, 42, 2498-2904.

Buesche, A. V., Cidav, Z., Knapp, M., \& Mandell, D. S. (2014). Costs of autism spectrum disorders in the United Kingdom and the United States. JAMA Pediatrics, 168, 721-728.

Carter, A. S., Messinger, D. S., Stone, W. L., Celimli, S., Nahmias, A. S., \& Yoder, P. (2011). A randomized controlled trial of Hanen's 'More Than Words' in toddlers with early autism symptoms. Journal of Child Psychology and Psychiatry, 52, 741-752. doi:10.1111/j.1469-7610.2011.02395.x 
Chambless, D. L., Sanderson, W. C., Shoham, V., Johnson, S. B., Pope, K. S., Crits-Christoph, P., ... Woody, S. R. (1996). An update on empirically validated therapies. Clinical Psychologist, 49, 5-18.

Cook, B. G., \& Cook, S. C. (2013). Unraveling evidence-based practices in special education. Journal of Special Education, 47, 71-82. doi:10.1177/0022466911420877

Croen, L. A., Shankute, N., Davignon, M., Massolo, M. L., \& Yoshida, C. (2017). Demographic and clinical characteristics associated with engagement in behavioral health treatment among children with Autism Spectrum Disorders. Journal of Autism and Developmental Disorders, 47, 3347-3357. doi:10.1007/s10803-017-3247-5

Dawson, G., Rogers, S., Munson, J., Smith, M., Winter, J., Greenson, J., ... Varley, J. (2010). Randomized, controlled trial of an intervention for toddlers with autism: the Early Start Denver Model. Pediatrics, 125, e17-e23.

Eldevik, S., Hastings, R. P., Hughes, J. C., Jahr, E., Eikeseth, S., \& Cross, S. (2009). Meta-analysis of early intensive behavioral intervention for children with autism. Journal of Clinical Child and Adolescent Psychology, 38, 439-450.

Eldevik, S., Hastings, R. P., Hughes, J. C., Jahr, E., Eikeseth, S., \& Cross, S. (2010). Using participant data to extend the evidence base for intensive behavioral intervention for children with autism. American Journal of Intellectual and Developmental Disabilities, 115, 381-405.

Estes, A., Zwaigenbaum, L., Gu, H., St. John, T., Paterson, S., Elison, J. T., ... IBIS Network. (2015). Behavioral, cognitive, and adaptive development in infants with autism spectrum disorder in the first 2 years of life. Journal of Neurodevelopmental Disorders, 7, 24. doi:10.1186/s11689-015-9117-6

Ferraioli, S., Hughes, C., \& Smith, T. (2005). A model for problem solving in discrete trial training for children with autism. Journal of Early Intensive Behavioral Intervention, 2, 224-246.

Fisher, W. W., Piazza, C. C., \& Roane, H. S. (2011). Handbook of applied behavior analysis. New York: Guilford Press.

Foxx, R. M. (2008). Applied Behavior Analysis treatment of autism: The state of the art. Child and Adolescent Psychiatric Clinics of North America, 17, 821-834. doi:10.1016/j.chc.2008.06.007

Freeman, S. K. (2007). The complete guide to autism treatments. A parent's handbook: Make sure your child gets what works. Lynden, WA: SKF Books.

Frith, U. (Ed.). (1991). Autism and Asperger syndrome. Cambridge, UK: Cambridge University Press.

Fuller, T., Pearson, M., Peters, J. L., \& Anderson, R. (2012). Evaluating the impact and use of transparent reporting of evaluations with non-randomised designs (TREND) reporting guidelines. British Medical Journal Open, 2, e002073. doi:10.1136/bmjopen-2012-002073

Grindle, C. F., Kovshoff, H., Hastings, R. P., \& Remington, B. (2009). Parents' experiences of homebased applied behavior analysis programs for young children with autism. Journal of Autism and Developmental Disorders, 39, 42-56. doi:10.1007/s10803-008-0597-z

Helt, M., Kelley, E., Kinsbourne, M., Pandey, J., Boorstein, H., Herbert, M., \& Fein, D. (2008). Can children with autism recover? If so, how? Neuropsychology Reviews, 18, 339-366. doi:10.1007/s11065-008-9075-9

Hertz-Picciotto, I., \& Delwiche, L. (2009). The rise in autism and the role of age at diagnosis. Epidemiology, 20, 84-90.

IACC. (2017). IACC strategic plan for autism spectrum disorder (ASD) research. Washington, DC: Interagency Autism Coordinating Committee, U.S. Department of Health and Human Services.

Ingersoll, B., Dvortcsak, A., Whalen, C., \& Sikora, D. (2005). The effects of a developmental, socialpragmatic language intervention on rate of expressive language production in young children with 
autistic spectrum disorders. Focus on Autism and Other Developmental Disabilities, 20, 213-222. doi:10.1177/10883576050200040301

Iovannone, R., Dunlap, G., Huber, H., \& Kincaid, D. (2003). Effective educational practices for students with autism spectrum disorders. Focus on Autism and Other Developmental Disabilities, 18, 150-165. doi:10.1177=10883576030180030301

Kanner, L. (1943). Autistic disturbances of affective contact. Nervous Child, 2, 217-250.

Kasari, C. (2015). Update on behavioral interventions for autism and developmental disabilities. Current Opinion Neurology, 28, 124-129.

Kasari, C., Lawton, K., Shih, W., Barker, T. V., Landa, R., Lord, C., ... Senturk, D. (2014). Caregiver-mediated intervention for low-resourced preschoolers with autism: an RCT. Pediatrics, 134, e72-e79.

Kendall, T., Megnin-Viggars, O., Gould, N., Taylor, C., Burt, L. R., \& Baird, G. (2013). Management of autism in children and young people: summary of NICE and SCIE guidance. BMJ: British Medical Journal, 347, f4865. doi:10.1136/bmj.f4865

Koegel, R. L., \& Koegel, L. K. (2012). The PRT pocket guide. Baltimore, MD: Brookes.

Kratochwill, T. R., \& Levin, J. R. (2014). Single-case intervention research: Methodological and statistical advances. Washington, DC: American Psychological Association.

Kratochwill, T. R., \& Shernoff, E. S. (2004). Evidence-based practice: Promoting evidence-based interventions in school psychology. School Psychology Review, 33, 34-48.

Kuppens, S., \& Onghena, P. (2012). Sequential meta-analysis to determine the sufficiency of cumulative knowledge: The case of early intensive behavioral intervention for children with autism spectrum disorders. Research in Autism Spectrum Disorders, 6, 168-176. doi:10.1016/j.rasd.2011.04.002

Lovaas, O. I. (1987). Behavioral treatment and normal educational and intellectual functioning in young autistic children. Journal of Consulting and Clinical Psychology, 55, 3-9.

Maglione, M. A., Gans, D., Das, L., Timbie, J., \& Kasari, C. (2012). Nonmedical interventions for children with ASD: Recommended guidelines and further research needs. Pediatrics, 130, S169-S178. doi:10.1542/peds.2012-0900O

Makrygianni, M. K., Gena, A., Katoudi, S., \& Galanis, P. (2018). The effectiveness of applied behavior analytic interventions for children with Autism Spectrum Disorder: A meta-analytic study. Research in Autism Spectrum Disorders, 51, 18-31. doi:10.1016/j.rasd.2018.03.006

Makrygianni, M. K., \& Reed, P. (2010). A meta-analytic review of the effectiveness of behavioural early intervention programs for children with Autistic Spectrum Disorders. Research in Autism Spectrum Disorders, 4, 577-593. doi:10.1016/j.rasd.2010.01.014

Mesibov, G. B., Shea, V., \& Schopler, E. (2004). The TEACCH approach to Autism Spectrum Disorders. New York: Springer.

Metz, B., Mulick, J. A., \& Butter, E. M. (2005). Autism: a late 20th century fad magnet. In J. Jacobson, R. M. Foxx, \& J. A. Mulick (Eds.), Controversial therapies for developmental disabilities: fads, fashion, and science in professional practice (pp. 45-60). Mahwah, NJ: Lawrence Erlbaum.

Moher, D., Hopewell, S., Schulz, K. F., Montori, V., Gwtzsche, P. C., Devereaux, P. J., ... Altman, D. G. (2010). CONSORT 2010 explanation and elaboration: updated guidelines for reporting parallel group randomised trials. BMJ, 340. doi:10.1136/bmj.c869

Myers, S. M., \& Johnson, C. P. (2007). Council on children with disabilities. Management of children with autism. Pediatrics, 120, 1162-1182.

National Autism Center. (2015). Evidence-based practice and autism in the schools. Randolph, MA: Author.

National Professional Development Center. (2013). The NPDC on ASD and the National Standards Project. 
New York State Department of Health Bureau of Early Intervention. (2017). New York State Department of Health Clinical Practice Guideline on assessment and intervention services for young children (age 0-3) with Autism Spectrum Disorders (ASD). Retrieved from https://www.health.ny.gov/community/infants_children/early_intervention/autism/docs/report_recommendations_update.pdf

Odom, S. L., Boyd, B., Hall, L., \& Hume, K. (2010). Evaluation of comprehensive treatment models for individuals with autism spectrum disorders. Journal of Autism and Developmental Disorders, 40, 425-436. doi:10.1007/s10803-009-0825-1

Odom, S. L., Brantlinger, E., Gersten, R., Horner, R. D., Thompson, B., \& Harris, K. (2004). Quality indicators for research in special education and guidelines for evidence-based practices: Executive summary. Arlington, VA: Council for Exceptional Children Division for Research.

Odom, S. L., Collet-Klingenberg, L., Rogers, S., \& Hatton, D. (2010). Evidence-based practices for children and youth with autism spectrum disorders. Preventing School Failure, 54, 275-282. doi:10.1080/10459881003785506

Odom, S. L., Thompson, J. L., Hedges, S., Boyd, B. A., Dykstra, J. R., Duda, M. A., ... Bord, A. (2015). Technology-aided interventions and instruction for adolescents with Autism Spectrum Disorder. Journal of Autism and Developmental Disorders, 45, 3805-3819. doi:10.1007/s10803-014-2320-6

Ogilvie, E., \& McCrudden, M. T. (2017). Evaluating the social validity of the Early Start Denver Model: A convergent mixed methods study. Journal of Autism and Developmental Disorders, 47, 2899-2910. doi:10.1007/s10803-017-3214-1

Orinstein, A. J., Helt, M., Troyb, E., Tyson, K. E., Barton, M. L., Eigsti, I. M., ... Fein, D. A. (2014). Intervention for optimal outcome in children and adolescents with a history of autism. Journal of Development and Behavioral Pediatrics, 35, 247-256.

Perry, A., Cummings, A., Dunn Geier, J., Freeman, N. L., Hughes, S., LaRose, L., ... Williams, J. (2008). Effectiveness of intensive behavioral intervention in a large, community-based program. Research in Autism Spectrum Disorders, 2, 621-642. doi:10.1016/j.rasd.2008.01.002

Peters-Scheffer, N., Didden, R., Korzilius, H., \& Sturmey, P. (2011). A meta-analytic study on the effectiveness of comprehensive ABA-based early intervention programs for children with autism spectrum disorders. Research in Autism Spectrum Disorders, 5, 60-69.

Reichow, B., Barton, E. E., Boyd, B. A., \& Hume, K. (2012). Early intensive behavioral intervention (EIBI) for young children with autism spectrum disorders (ASD). Cochrane Database of Systematic Reviews, 10. doi:CD009260

Reichow, B., Doehring, P., Cicchetti, D. V., \& Volkmar, F. R. (2011). Evidence-based practices and treatments for children with autism. New York: Springer.

Reichow, B., \& Wolery, M. (2008). Comprehensive synthesis of early intensive behavioral interventions for young children with autism based on the UCLA Young Autism Project Model.Journal of Autism and Developmental Disorders, 39, 23-41. doi:10.1007/s10803-008-0596-0

Rogers, S. J. (1998). Neuropsychology of autism in young children and its implications for early intervention. Mental Retardation and Developmental Disabilities Research Revieres, 4, 104-112.

Rogers, S. J., \& Vismara, L. A. (2008). Evidence-based comprehensive treatments for early autism. Journal of Clinical Child and Adolescent Psychology, 37, 8-38. doi:10.1080=15374410701817808

Sackett, D. L., Rosenberg, W. M., Gray, J. M., Haynes, R. B., \& Richardson, W. S. (1996). Evidence-based medicine: What it is and what it isn't. British Medical Journal, 312, 71-72. doi:10.1136/bmj.312.7023.71

Simpson, R. L., Mundschenk, N. A., \& Heflin, L. J. (2011). Issues, policies, and recommendations for improving the education of learners with autism spectrum disorders. Journal of Disability Policy Studies, 22, 3-17. doi:10.1177/1044207310394850 
Skinner, B. F. (1938). The Behavior of organisms: An experimental analysis. New York: AppletonCentury.

Smith, T. (1996). Are other treatments effective? In C. Maurice, G. Green, \& S. C. Luce (Eds.), Behavioral intervention for young children with autism: a manual for parents and professionals (pp. 45-62). Austin, TX: Pro-Ed.

Smith, T. (2005). The appeal of unvalidated treatments. In J. Jacobson, R. M. Foxx, \& J. A. Mulick (Eds.), Controversial therapies for developmental disabilities: fads, fashion, and science in professional practice (pp. 45-60). Mahwah, NJ: Lawrence Erlbaum.

Smith, T. (2011). Applied behavior analysis and early intensive intervention. In D. G. Amaral, G. Dawson, \& D. H. Geschwind (Eds.), Autism spectrum disorders (pp. 1037-1055). New York: Oxford University Press.

Smith, T., \& Iadarola, S. (2015). Evidence base update for autism spectrum disorder.Journal of Clinical Child and Adolescent Psychology, 44, 897-922.

Spreckley, M., \& Boyd, R. (2009). Efficacy of applied behavioral intervention in preschool children with Autism for improving cognitive, language, and adaptive behavior: A systematic review and meta-analysis. The Journal of Pediatrics, 154, 338-344.

Strain, P. S., \& Bovey, E. (2011). Randomized, controlled trial of the LEAP model of early intervention for young children with autism spectrum disorders. Topics in Early Childhood Special Education, 313, 133-154. doi:10.1177/0271121411408740.

Suhrheinrich, J., Hall, L. J., Reed, S. R., Stahmer, A. C., \& Schreibman, L. (2014). Evidence based interventions in the classroom. In L. Wilkinson (Ed.), Autism spectrum disorder in children and adolescents: Evidence-based assessment and intervention in schools (pp. 151-172). Washington, DC: American Psychological Association.

Thomas, K. C., Morrissey, J. P., \& McLaurin, C. (2007). Use of autism-related services by families and children. Journal of Autism and Developmental Disorders, 37, 818-829. doi:10.1007/s10803-0060208-9

Thompson, T. (2013). Autism research and services for young children: history, progress and challenges. Journal of Applied Research in Intellectual Disabilities, 26, 81-107.

Virués-Ortega, J. (2010). Applied behavior analytic intervention for autism in early childhood: Metaanalysis, mega-regression and dose-response meta-analysis of multiple outcomes. Clinical Psychology Review, 30, 387-399.

Vismara, L. A., \& Rogers, S. J. (2010). Behavioral treatments in Autism Spectrum Disorder: What do we know? Annual Review of Clinical Psychology, 6, 447-468. doi:10.1146/annurev.clinpsy.121208.131151

Warren, Z., McPheeters, M. L., Sathe, N., Foss-Feig, J. H., Glasser, A., \& Veenstra-Vanderweele, J. (2011). A systematic review of early intensive intervention for autism spectrum disorders. Pediatrics, 127, e1303-e1311.

Weitlauf, A. S., McPheeters, M., Peters, B., Sathe, N., Travis, R., Aiello, R., ... Warren, Z. (2014). Therapies for children with Autism Spectrum Disorder: Behavioral interventions update (Publication No. EHC2013-09-0038.R1). Rockville, MD: AHRQ (US Agency for Healthcare Research and Quality).

Wolf, M., Risley, T. R., \& Mees, H. L. (1964). Applications of operant conditioning and procedures to the behavior problems of an autistic child. Behaviour Research and Therapy, 1, 305-312.

Wong, C., Odom, S. L., Hume, K., Cox, A. W., Fettig, A., Kucharczyk, S., \& Schultz, T. R. (2013). Evidence-based practices for children, youth, and young adults with Autism Spectrum Disorder. Chapel Hill, NC: The University of North Carolina, Frank Porter Graham Child Development Institute, Autism Evidence-Based Practice Review Group. 
Wong, C., Odom, S. L., Hume, K. A., Cox, A. W., Fettig, A., Kucharczyk, S., ... Schultz, T. R. (2015). Evidence-based practices for children, youth, and young adults with Autism Spectrum Disorder: A comprehensive review. Journal of Autism and Developmental Disorders, 45, 1951-1966. doi:10.1007/s10803-014-2351-z

Elena L. Grigorenko - Hugh Roy and Lillie Cranz Cullen Distinguished Professor, Department of Psychology, University of Houston; Research Certified Adjunct Professor, Departments of Pediatrics and Molecular and Human Genetics, Baylor College of Medicine; Leading Researcher, Saint Petersburg State University, Ph.D.

Research area: cognitive development, developmental disabilities, neuropsychiatric genetics.

E-mail: Elena.grigorenko@yale.edu

Stephanie Torres - Graduate Student, Department of Psychology, University of Houston.

Research area: child neuropsychology.

E-mail: sttorres91@gmail.com

Evgeniya I. Lebedeva - Senior Researcher, Institute of Psychology of Russian Academy of Sciences; Head of Scientific Department, Association of Non-profit Organizations Created by Parents of Children with Autism Spectrum Disorders "Autism Regions”, Ph.D.

Research area: autism spectrum disorder, cognitive development, theory of mind.

E-mail: evlebedeva@yandex.ru

Yevgeniy A. Bondar - Management Board Member, Association of Non-profit Organizations Created by Parents of Children with Autism Spectrum Disorders "Autism Regions"; Leading Research Fellow, Novosibirsk State University, Ph.D.

Research area: autism spectrum disorder, evidence-based practices, early intervention, applied behaviour analysis.

E-mail: bond@itam.nsc.ru

\title{
Вмешательства при РАС с доказанной эффективностью: акцент на вмешательствах, основанных на прикладном анализе поведения (ПАП)
}

\author{
Е.Л. Григоренко ${ }^{\mathrm{a}, \mathrm{b}}$, С. Торрес ${ }^{\mathrm{b}}$, Е.И. Лебедева ${ }^{\mathrm{c}, \mathrm{d}}$, Е.А. Бондарь ${ }^{\mathrm{d}, \mathrm{e}}$
}

\section{Резюме}

Настоящий обзор освещает последние тенденции в области психолого-педагогических вмешательств для детей с расстройствами аутистического спектра (РАC) с учетом стремительного роста числа публикаций по этой тематике в последние несколько лет. В настоящий момент внимание специалистов в области вмешательств при РАС сосредоточено на соблюдении стандартов научной доказательности и высоком качестве исследований. Согласно недавним систематическим обзорам, все комплексные программы вмешательства для детей с РАС с доказанной эффективностью в той или иной степени основаны на научной дисциплине прикладного анализа поведения (ПАП). Реализация таких интенсивных поведенческих программ улучшает траекторию развития ребенка с PAC. В частности, метааналитические исследования демонстрируют существенное 
улучшение показателей IQ и адаптивного поведения у детей, помощь которым оказывалась в рамках ранних интенсивных комплексных программ, основанных на ПАП. Более того, большинство целевых вмешательств с доказанной эффективностью для детей с РАС либо также основаны на ПАП, либо являются компонентами комплексных программ вмешательств, основанных на ПАП. В последнее время возрастает интерес к модульным вмешательствам, которые позволяют обеспечить высокую степень индивидуализации программы помощи для каждого ребенка с РАС, в то же время удовлетворяя стандартам научной доказательности. Рост числа строгих оценок эффективности различных вмешательств, применяемых в реальных неклинических условиях для компенсации основных дефицитов, связанных с РАС, создает адекватную базу для внедрения и широкого использования вмешательств с доказанной эффективностью в системе помощи людям с РАС, в том числе неспециалистами, прошедшими базовую подготовку.

Ключевые слова: расстройство аутистического спектра, поведенческие вмешательства, прикладной анализ поведения, вмешательства с доказанной эффективностью.

Григоренко Елена Леонидовна - профессор, факультет психологии, Хьюстонский университет; ведущий ученый, Лаборатория междисциплинарных исследований развития человека, Санкт-Петербургский государственный университет, доктор психологических наук, Ph.D.

Сфера научных интересов: когнитивное развитие, атипичные траектории развития, нейропсихиатрическая генетика.

Контакты: Elena.grigorenko@yale.edu

Торрес Стефани - аспирант, факультет психологии, Хьюстонский университет.

Сфера научных интересов: детская нейропсихология.

Контакты: sttorres91@gmail.com

Лебедева Евгения Игоревна - старший научный сотрудник, ФГБУН «Институт психологии РАН»; руководитель центра ответственности «Наука», Ассоциация некоммерческих организаций, созданных родителями детей с расстройствами аутистического спектра, «Аутизм-Регионы», кандидат психологических наук.

Сфера научных интересов: расстройство аутистического спектра, когнитивное развитие, модель психического.

Контакты: evlebedeva@yandex.ru

Бондарь Евгений Александрович - член правления, Ассоциация некоммерческих организаций, созданных родителями детей с расстройствами аутистического спектра, «АутизмРегионы»; ведущий научный сотрудник, Новосибирский государственный университет, кандидат физико-математических наук.

Сфера научных интересов: расстройство аутистического спектра, практики с доказанной эффективностью, раннее вмешательство, прикладной анализ поведения.

Контакты: bond@itam.nsc.ru 